\title{
ON A NEW SPECIES OF THE GENUS CALLIANASSA (CRUSTACEA, DECAPODA) FROM THAILAND
}

With 2 Text-figures

by

\author{
Katsushi SAKAI
}

(Laboratory of Crustacea, Shikoku Women's University)

タイ国産スナモグリ属 (十脚甲殼類) の一新種, ラノングスナモグリについて

捰図 2

酒 井 勝 司*

(四国女子大学)

Recently several Callianassid specimens, white, measuring about $70 \mathrm{~mm}$ in total length, and with characteristics of having the thick dactylus of larger cheliped, were sent to the present author by Dr. Kinji WADA of the Seto marine biological Station of Kyoto University in Wakayama Prefecture. This is the first record of Callianassa from Thailand, and seems to be a new species.

\section{Callianassa (Callichirus) ranongensis sp. nov.}

Material examined. $-6 \hat{\mathrm{O}}$, tl 30-70 mm, 1우, tl $65 \mathrm{~mm}$, BLT 1704-1710, collected on muddy area of the mangrove swamp, Hatsaikhao, Ranong Province, Thailand, 7 th XII, 1982, Keiji WADA leg.

Diagnosis. - Frontal margin of carapace trispinose. Telson oblong, and slightly convex on posterior margin. Uropod distinctly longer than telson, endopod lanceolate and evidently shorter than exopod. 1st pereiopod unequal; in larger cheliped ischium denticulate on ventral margin, merus armed with an acute proximal tooth on ventral margin, and both dactylus and fixed finger denticulate on cutting edges.

Description. - The frontal margin of the carapace is trispinose (Fig. 1a-b); the rostrum is sharply pointed and triangular in dorsal view, reaching the level of the proximal one third of the eye-stalk, and a pair of frontal lateral teeth is obtuse, situated both at the

* 住所: 四国女子大学生物学教室, 771-11 德島市応神町古川 Laboratory of Crustacea, Shikoku Women's University, 771-11 Tokushima, Ohjincho-Furukawa, Japan. 
lateral one fourth. At some distance from the frontal margin the dorsal surface of carapace is convex. The cervical groove lies at the posterior one third of the carapace.

The eye-stalks show an elongate triangle with an obtuse tip, extending forward to the level of the distal margin of the proximal segment of the antennule; the cornea is situated anterior to the midline. The 2nd segment of the antennule is slightly shorter than the proximal one, and the flagellae are about as long as the peduncle. The antennal

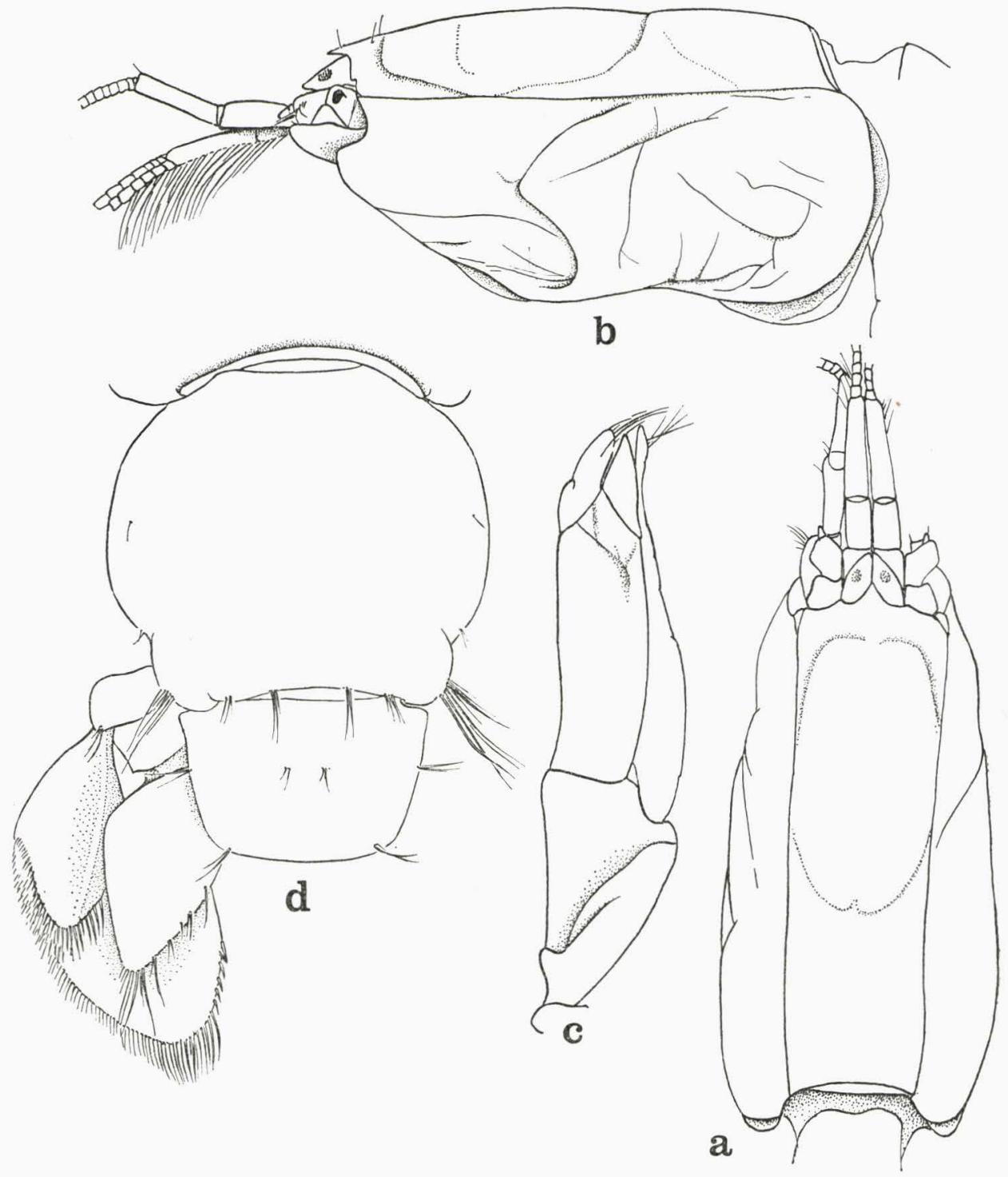

Fig. 1. Callianassa (Callichirus) ranongensis sp. nov. a, carapace in dorsal view. b, same in lateral view. c, 2nd pleopod of males in posterior view. d, 6th abdominal segment and tail-fan in dorsal view. 
peduncles overreach the antennular ones by the distal one third of the terminal segment; the scaphocerite is a small triangle in shape.

The 3rd maxillipeds (Fig. 2a) are typical for Callichirus s. str. The ischium and merus are broad, jointed each other to form a broad plate. The propodus is largely protruded on the posterior margin. The dactylus is sickle-shaped, terminated with a rounded tip.

The 1st pereiopods are unequal and not different between males and females. In the larger cheliped (Fig. 2b-c) the ischium is smooth on the dorsal margin, while minutely denticulate on the ventral margin. The merus is oblong, and about one fourth the length of ischium; the ventral margin is smooth, provided with a proximal hook usually terminated with an acute tip, and the dorsal margin is also smooth, largely concave at the proximal part. The carpus is broad, and about two-thirds times as long as the merus and 1.5 times as broad as long. The chela is also broad, slightly longer than the carpus, and slightly broader than long along the dorsal margin. The outer distal joint with the dactylus lies at the proximal two-fifths of the length. The fixed finger is denticulate on the cutting edge; the proximal tooth is noticeable in form, situated slightly below the outer distal joint. The dactylus is smooth and largely convex on the outer surface; the cutting ede is denticulate on the whole margin, and incurved distally.

In the smaller cheliped (Fig. 2d) the ischium is denticulate on the ventral margin, while smooth on the dorsal margin. The merus is about as long as the ischium, and smooth on the dorsal and ventral margins. The carpus is broad, about as long as broad, and three-fourths the length of the merus. The chela is about as long as the carpus along the dorsal margin. The fixed finger is slender; the outer surface is medially beset with a row of hair-tufts, and the cutting edge is minutely denticulate outside. The dactylus is also slender; the outer surface is medially provided with a row of hair-tufts, and the cutting edge is also minutely denticulate outside.

The 2nd pereiopods are chelate. The 3rd pereiopods (Fig. 2e) are simple; the propodus is broadened, the posterior margin of which is truncate, and the distal margin is largely concave at the middle. The dactylus is small and terminated with an acute tip. The 4 th pereiopods are simple, and the 5 th chelate.

The 1st pleopods in males are two-segmented, the distal segment is short and bilobed at the tip; the 2nd pleopods (Fig. 1c) are bifulcate in narrow foliaceous form, the exopod is simple, while the endopod is bilobed, bearing an appendix interna. The 1st pleopods in females are three-segmented in pediform; the 2nd pleopods are bifulcate in pediform, the exopod of which is simple, while the endopod bilobed, provided with an appendix interna, which is about half the length of the outer lobe. The 3rd to 5 th pleopods in both sexes are bifurcate in broad foliaceous form.

The telson (Fig. 1d) is oblong, two-thirds times as long as broad, the posterior margin is slightly convex. The uropods are distinctly longer than telson. The protopod 

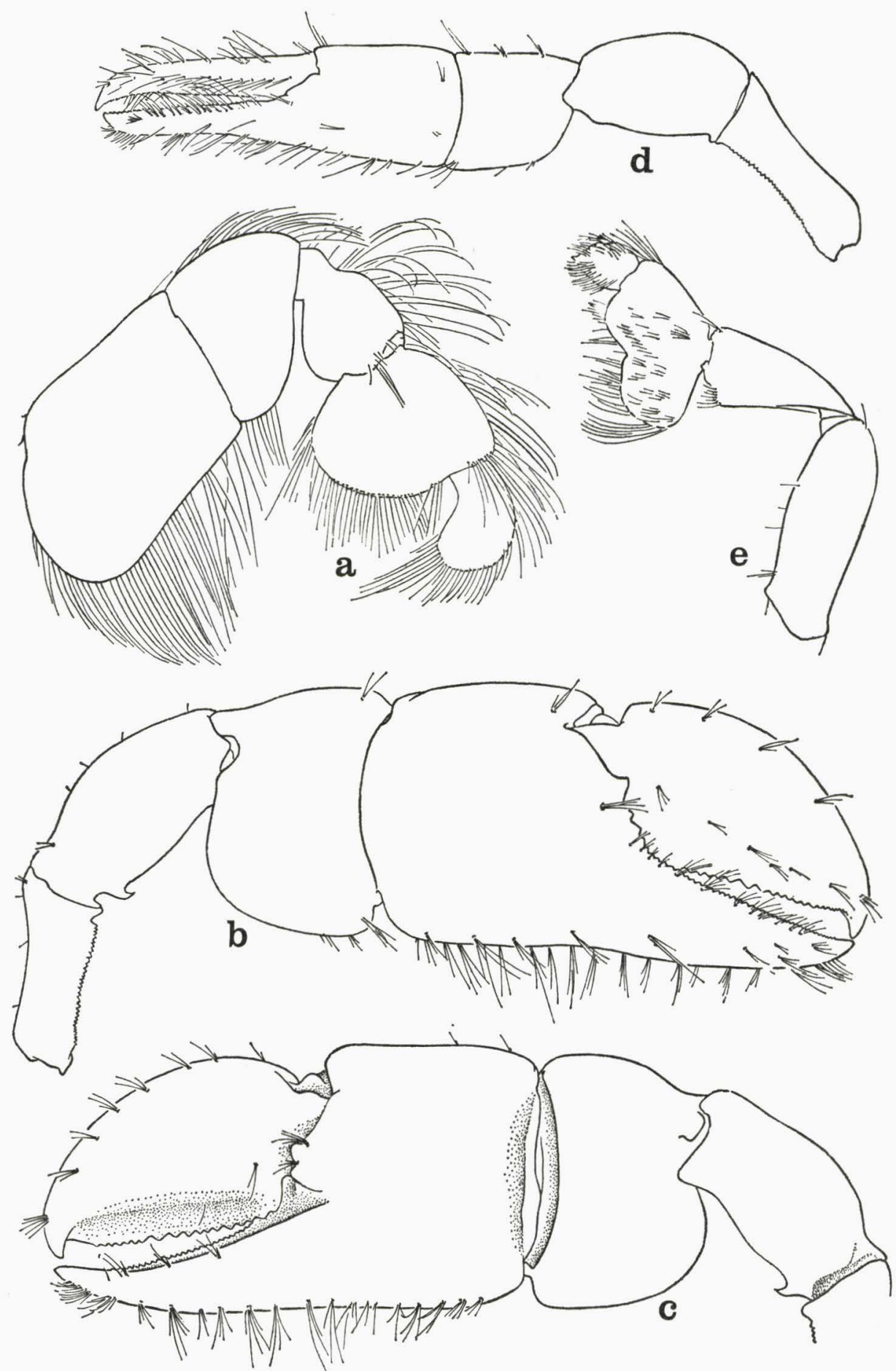

Fig. 2. Callianassa (Callichirus) ranongensis sp. nov. a, 3rd maxilliped in outer view. b, larger cheliped in outer view. c, same in inner view. d, smaller cheliped in outer view. e, 3rd pereiopod in outer view. 
is broad. The exopod is about two times the length of the telson, and slightly convex on the inner margin; a proximal tooth is remarkable. The endopod is lanceolate in shape, about 1.5 times as long as the telson.

The type series is designated as follows.

Holotype: $\quad 1 \hat{\delta}$, tl $70 \mathrm{~mm}$, BLT 1704.

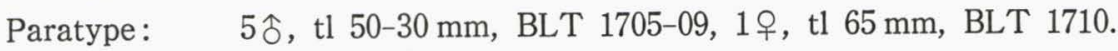

Type-locality: Hatsaikhao, Ranong Province, Thailand.

Remarks.-The present species is related to Callianassa (Cheramus) joculatrix DE MAN from Indonesia area, because in the larger 1st pereiopod the ischium is denticulate on the ventral margin, and the merus bears a proximal tooth on the ventral margi, however DE MAN's species clearly differs from it in that the tail-fan is not characteristic for Callichirus s. str. Concerning the thickness of the dactylus of larger 1st pereiopod the present species hints Call. (Cheramus) pachydactyla A. Milne-Edwards from the Cape Verde Islands.

\section{Acknowledgements}

Throughout the course of this study the present author is most grateful to Dr. Keiji WADA of the Seto marine biological Station of the Kyoto University, who submitted so kindly his valuable collections together with its data to his present works.

\section{References}

Man, J.G. De 1928. The Decapoda of the Siboga-Expedition. Part 7. Thalassinidae and Callianassidae collected by the Siboga Expedition with some remarks on the Laomedidae. Siboga Exp. $39 \mathrm{a}(6)$ : 1-187, Pls. 1-10.

Milne-Edwards, A. 1870. Révision du genre Callianassa (Leach). Nouv. Arch. Mus. Hist. nat. Paris $6: 75-102$, Pls . 1-2.

摘

要

1982 年京都大学が行なつたマレー半島のタイ領ラノング市郊外のマングローブ地帯の調査の 際, 大型の $70 \mathrm{~mm}$ に達するスナモグリ属の 1 種が多数採集された。このスナモグリ属の一種 は新種で地名をとりラノングスナモグリと名付けられた。 